\title{
MEDISCH ETHISCHE BESCHOUWINGEN OVER ORGAANTRANSPLANTATIE
}

De medische kennis is in de laatste decennia aanzienlijk vergroot. Deze kennistoeneming is gepaard gegaan met een vermeerdering van het medisch kunnen. Nieuwe theorieën gingen vergezeld van nieuwe mogelijkheden. Zo is ook de orgaantransplantatie tot grote bloei gekomen door beheersing van de heelkundige techniek, maar vooral ook van de immunologische afweermechanismen. Een geheel.nieuw veld is opengelegd. Het is geboden om naast het juichen over deze vorderingen ook kritisch stil te staan en zich af te vragen: wat doen wij? Is het in medisch-ethisch opzicht geoorloofd om zo te handelen? En overschrijden wij de grenzen van het toelaatbare niet? In een aantal hoofdstukjes zullen wij ons hierop bezinnen.

\section{WAT IS TRANSPLANTATIE?}

Onder transplantatie verstaan wij het overbrengen van weefsel van de plaats, waar het normaal werd aangelegd, naar een andere plaats, met de bedoeling dat het zijn functie of althans een deel van zijn functie, op die andere plaats voortzet. Deze definitie is zeer algemeen gehouden, $\mathrm{d}$ w $\mathrm{z}$ dat vele situaties waarbij weefsel overgebracht wordt, vallen onder de definitie van transplantatie. Daardoor nemen wij het gehele gebied van de transplantatie in beschouwing en beperken wij ons niet tot een bepaalde vorm daarvan.

Voorwaarde van elke transplantatie is dus dat het weefsel of het orgaan dat men overplaatst, zijn functie na de overplaatsing verricht in de situatie waarin het dan is geplaatst. Deze voorwaarde is begrijpelijk, want juist om deze reden wordt de transplantatie uitgevoerd. Het doel immers is om mensen (c q dieren) daarmee te helpen door een falend orgaan of weefsel bij hen te vervangen.

Uitdrukkelijk zij vermeld, dat niet in elk geval alle functies van het betreffende overgeplante orgaan intact dienen te blijven. Zo heeft de huid verschillende functies als bedekking, afscherming tegen infecties van buiten, maar ook functies in de vorm van regulatie van warmte-afgifte, zweetsecretie e d. Transplantatie van een stuk huid $k a n$ bij grote verwondingen $b \mathrm{v}$ gedaan worden in verband met de afschermende functie, terwijl de warmte-regulerende functie in de nieuwe situatie niet kan blijven voortbestaan. De transplantatie geschieade dan ook niet vanwege deze laatste functie. 


\section{ZIJN ER BEZWAREN TEGEN TRANSPLANTATIE BIJ DE MENS?}

Als men zich afvraagt of er bezwaren zijn tegen transplantatie bij de mens, dient men in ogenschouw te nemen of door een dergelijke ingreep schade wordt aangericht van een dusdanige aard, dat het niet verantwoord is het voordeel van de transplantatie te accepteren boven de aangerichte schade. Dit betreft dan zowel de schade die wordt aangericht bij degene, die weefsel afstaat (donor) alswel bij degene, die weefsel ontvangt (ontvanger).

Men bedenke, dat transplantatie ook zodanig kan plaatsvinden dat dezelfde persoon gever en ontvanger is. $D_{k} i$ komt nogal eens voor bij huidtransplantaties. Van medisch ethische ijjde kan nauwelijks bezwaar gemaakt worden tegen een dergelijke transplantatie bij één en dezelfde mens, als het te verwachten is dat de patiënt van het getransplanteerde huidweefsel baat zal hebben, terwijl anderzijds het verwijderen van huidweefsel hem geen grote schade zal berokken. Om een voorbeeld te noemen van iemand die een grote wond heeft aan het onderbeen, waarvan de huid zich niet herstelt of bij herstel zich zo zal samentrekken (zoals wij dit van littekenweefsel kennen), dat de functie van de spieren ernstig wordt belemmerd, dan is van medisch ethische zijde geen enkel bezwaar om huid naar dit gebied te transplanteren waardoor a) de wond sneller zal kunnen genezen, b) de functie van de spieren behouden blijft. Er is geen bezwaar tegen als huid gebruikt word $\mathrm{b} v \mathrm{v}$ van het bovenbeen of van de onderarm of van de buikhuid, maar het zou wel bezwaarlijk zijn als men daarvoor huid zou nemen uit het gelaat, omdat dan overmijdelijk ontstane littekens schade aan het gelaat zouden aanrichten. De psychische expressie gaat daardoor verloren en de patiënt zelf zou ook door zijn totaal ander voorkomen in het sociale milieu geschaad worden en daar psychisch ernstig onder kunnen lijden. Dit zou ethisch niet geoorloofd zijn.

Het zou echter weer wel toelaatbaar zijn, indien het om een of andere reden niet mogelijk zou zijn elders van het lichaam huid te verkrijgen of van een ander mens huid te gebruiken voor de transplantatie, terwijl er een absolute noodzaak tot transplantatie is om de patiěnt aan de verwonding niet te laten sterven.

Uit dit alles kunnen wij de gevolgtrekking maken, dat tegen transplantatie in principe geen medisch ethische bezwaren bestaan, maar dat ieder afzonderlijk geval weer op zijn eigen merites bekeken zal dienen te worden. 


\section{ZIJN ER ANDERE DAN MEDISCH ETHISCHE BEZWAREN?}

Transplantatie is vooral de laatste jaren binnen het oogbereik van he: grote publiek gekomen door de orgaantransplantaties die in de pers vaak min of meer heroik worden afgeschilderd. Men vergeet daarbij dat reeds jarenlang transplantaties worden toegepast. Aan het begin van deze eeuw werd bloedtransfusie mogelijk, doordat Landsteiner in 1900 de bloedgroepen ontdekte en daarbij bovendien vaststelde dat bloed gemakkelijk vervangen kan worden door bloed met dezelfde bloedgroep. Wanneer echter bloed wordt samengebracht met bloed van een andere groep, dan ontstaan er complicaties, waardoor de functie van het bloed verloren gaat. Sindsdien worden dagelijks talloze bloedtransfusies gegeven. Al die tijd is er sprake geweest van transplantatie van weefsel van de ene mens op (in) het lichaam van een ander mens. Weinig mensen nu blijken bezwaren te hebben tegen bloedtransfusies.

Het is algemeen bekend dat de donor vrijwel nimmer kwade gevolgen ondervindt van het afnemen van bloed voor transfusie. Uiteraard gaat men uit van een gezonde donor. De ontvanger ondervindt over het algemeen grote baat van een transfusie. Bezwaren, die aangevoerd worden tegen bloedtransfusies zijn dan ook niet van medisch ethische aard, maar van religieuse aard.

De Jehova Getuigen achten bloedtransfusies volstrekt ongeoorloofd. Hun standpunt berust op religieuse gronden. In het kort gezegd zijn zij van mening dat bloed leven is en leven is van God gegeven. Daar mag men niet mee manipuleren. Zo laat een Jehova Getuige en enkele anderen die een dergelijke religieuse overtuiging $\mathrm{t}$ a $\mathrm{v}$ bloedtransfusies aanhangen, zijn kind dat zonder bloedtransfusie ten dode is opgeschreven, sterven zonder de heilbrengende ingreep van bloedtransfusie te willen toestaan. Voor de behandelende arts is dit een zeer frustrerende zaak. Hij zal trachten de ouders te overtuigen. Als de patiënt die een bloedtransfusie nodig heeft, en deze op grond van zijn geloofsovertuiging weigert, zal de arts proberen deze mening van de patiënt te veranderen. Als deze volwassen is en dus de consequentie van zijn mening, die hij baseert op zijn geloofsovertuiging, kan overzien, zal tenslotte iedere arts deze mening dienen te respecteren. Hij zal geen bløedtransfusie mogen geven, ook niet op een dergelijke manier, dat de patiënt, het niet kan merken, b v onder narcose.

$\mathrm{Bij}$ grote operaties betekent dit in de praktijk dat er soms zodanige bezwaren zijn van de kant van de medische staf, dat van een dergelijke operatie moet worden afgezien. De medici willen de verant- 
woordelijkheid voor de ingreep met zo 'n sterk verhoogd risico niet dragen. Ook al betekent dit dat de patiënt menselijkerwijze gesproken, snel aan zijn aandoening zal overlijden.

\section{WELKE VORMEN VAN TRANSPLANTATIE KENNEN WIJ?}

Over het algemeen vindt transplantatie plaats binnen dezelfde soort. Toch wordt ook het overbrengen van weefsel van een dier op een mens verricht. Voor transplantatie van belangrijke organen van de mens zal dit echter, naar verwachting, niet mogelijk zijn. Het meest bekende voorbeeld van een dergelijke transplantatie, is het gebruik van botweefsel (kalfsbotten), maar dit heeft geen grote vlucht genomen en is meestal in het experimentele stadium gebleven. Hetzelfde geldt voor de inbrenging van endocr ne organen van een dier bij de mens. De verhalen zijn legio van verjongingskuren door het gebruik van apenklieren, maar praktisch is dit nooit verder gekomen dan een experiment.

Toch wordt nog steeds in deze richting gezocht om de begrijpelijke reden, dat bij iedere transplantatie het aanbod van organen of weefsels beperkt is, omdat deze alleen van gezonde mensen, die hiertoe toestemming verlenen, kunnen worden gebruikt. Dit probleem, te weten dus de beschikbaarheid van donor-organen, zou aanzienlijk worden opgelost als van weefsels of organen van dieren kan worden gebruik gemaakt. Men spreekt in zo 'n geval van hetero-transplantatie, $\mathrm{d} \mathbf{w} \mathrm{z}$ transplantatie tussen leden van verschillende soort. De andere vorm is de iso-transplantatie, $\mathrm{d} \mathrm{w} \mathrm{z}$ transplantatie tussen leden van dezelfde soort. Dit betekent voor de mens dus van mens op mens, waarbij weer onderscheid gemaakt kan worden tussen auto-transplantatie $\mathrm{d} \mathrm{w} \mathrm{z}$ van mens op diezelfde mens en homotransplantatie $\mathrm{d} \mathrm{w} \mathrm{z}$ van een mens op een ander mens. In het voorafgaande zijn al enkele voorbeelden gegeven. Zo wordt de huidtransplantatie vaak van de mens op diezelfde mens uitgevoerd (autotransplantatie), maar ook wel van de ene mens op de andere (homotransplantatie). Bloedtransfusie is vrijwel steeds homo-transplantatie.

(Ook met bloedtransfusie komt het voor dat men transplanteert van de ene mens op diezelfde mens. Men neemt dan $b \mathrm{v}$ voor te verwachten grote operaties waarbij veel bloed nodig is, op regelmatige tijden bloed van de patiënt af, bewaart dit totdat men voldoende heeft om diezelfde patiënt te kunnen opereren, terwijl deze intussen zijn bloed weer heeft aangemaakt. Het eigen bloed staat dan weer ter beschikking van die patiënt bij de operatie. In de praktijk komt dit ook nog in een andere vorm voor. Wanneer men bij iemand bloed heeft afgenomen voor een transfusie en deze donor overkomt een on- 
geluk vlak na die afneming van het bloed, waarbij hij ernstig bloedverlies heeft, dan geeft men hem het eigen bloed weer terug. In het laatste geval was het uiteraard niet de intentie om bij het afnemen van het weefsel dit weer aan diezelfde mens toe te dienen).

Transplantatie van de ene mens op de andere betreft een grote hoeveelheid van organen en weefsels: bloed, huid, botten, nieren, harten, longen, lever, pancreas, beenmerg.

Tenslotte zij vermeld dat onder bepaalde voorwaarden organen voor transplantatie kunnen worden gebruikt van een dood mens.

In een volgende paragraaf zal over de bijzondere voorwaarden die hierbij gelden, nader worden ingegaan.

5. VOORWAARDEN VOOR ORGAANTRANSPLANTATIE

In de eerste plaats moet aandacht aan het volgende worden besteed. Indien bij een mens een vreemd lichaam wordt ingebracht, dan treden, reacties op die tot doel hebben het lichaam van het ingebrachte vreemde voorwerp te bevrijden. Dat gebeurt ook bij weefsels, zowel van dieren als van mensen. Dit is de oorzaak, dat de praktijk van de transplantatie zoveel later tot stand kwam dan de gedachte eraan. Want het zo maar overbrengen van de huid van de ene mens op de andere veroorzaakt een zogenaamde afstottingsreactie bij de mens die de huid kreeg, waardoor het nieuwe huidgedeelte afsterft. Dit gebeurt ook bij organen. De bloedtransfusie, die de eerste wefeseltransplantatie is die in grote getale werd uitgevoerd, is eveneens afhankelijk van het feit of het bloed van de gever en het bloed van de ontvanger bij elkaar passen. Voor het bloed had Landsteiner 4 groepen gevonden en als het donorbloed en het bloed van de ontvanger dezelfde groep hebben, dan is er geen gevaar voor moeilijkheben te duchten. Dit laatste met een heel kleine uitzondering.

Vooral de laatste jaren is men er door verdere studie achter gekomen dat er meer groepen bestaan, meer onderscheid is, waardoor moeilijkheden kunnen optreden. Als er overeenstemming tussen weefsels van donor en ontvanger is, spreekt men van compatibiliteit. Zo niet, dan van incompatibiliteit.

De eerste voorwaarde voor transplantatie is, dat er tussen de weefzels van gever en ontvanger compatibiliteit bestaat. De fraaiste compatibiliteit wordt gevonden bij de eeneiīge tweeling. Het geeft geen moeilijkheden om de nier van een eeneiïge tweeling op de andere tweeling over te plaatsen. De weefsels zijn volledig compatibel. Maar buiten de eeneiige tweeling zijn er grote moeilijkheden op 
dit gebied. In de eerste plaats al omdat wij niet precies weten welke factoren allemaal bijdragen aan de compatibiliteit en incompatibiliteit van de weefsels. In de tweede plaats is het moeilijk om deze factoren te onderzoeken.

In Europa is men er daartoe overgegaan Eurotransplant te stichten (door Prof Dr $\mathrm{J}$ van Rood). Deze stichting is in Leiden gevestigd en verzamelt van mensen die in aanmerking komen voor een donor-orgaan alle gegevens, voor zover mogelijk ten aanzien van de factoren die bijdragen tot de compatibiliteit. Deze zelfde gegevens worden van de donor eveneens verkregen en met behulp van een computer in Leiden wordt de beste compatibiliteitstoestand uitgezocht. Dat wil dus zeggen dat bij het aangeboden donororgaan de meest passende ontvanger wordt bepaald, zodat de meeste kans op overleven van het donororgaan bestaat.

Een tweede voorwaarde voor orgaantransplantastie betreft de toestand waarin de ontvanger verkeert. Over het algemeen zal zijn conditie niet goed zijn omdat bij hem juist een belangrijk orgaan in zijn functie faalt. Daar dient rekening mee gehouden te worden. Maar wel zal hij voor het ondergaan van de ingreep om een donororgaan in te brengen, in een zo goed mogelijke conditie moeten verkeren, gezien zijn situatie. Omdat de compatibiliteitsfactoren niet volledig bekend zijn, treden er toch vrij veel afstotingsreacties op. Dit afweermechanisme kan worden bedwongen met medicijnen in hoge doseringen, met name bijnierschorshormonen en immunosuppressiva. Deze medicamenten zijn verre van onschadelijk en kunnen op zich ook de ontvanger aantasten. Om die reden is het verstandig dat de conditie van de ontvanger zo goed mogelijk is.

De derde voorwaarde gaat over de toestand waarin de gever van een orgaan verkeert. Het zal duidelijk zijn dat het voor hem het beste is als ook hij in een goede conditie verkeert, want hij moet een orgaan afstaan waarvan uiteraard na voorafgaand onderzoek gebleken is dat dit mogelijk zal zijn. Het zou ook kunnen zijn dat een orgaan nodig is voor transplantatie dat voor de gever essentieel is, dus van vitaal belang. In dat geval betekent het afstaan van het orgaan de dood van de gever, b.v. hart of longen. Het is uiteraard een niet geoorloofde ingreep om iemand te doden, alleen om een orgaan van hem in handen te krijgen. De praktische situatie is dan ook omgekeerd: het over te planten orgaan wordt verkregen van een reeds overleden mens.

Als vierde voorwaarde voor orgaantransplantatie dient aandacht besteed te worden aan de toestand waarin het donorgaan verkeert. 
Ook hiervan zal men als begrijpelijke eisen stellen dat het een volkomen gezond, goed levend orgaan dient te zijn. Als de donor in leven is en het tijd is om de transplantatie te programmeren, zijn hier geen moeilijkheben. Het onderzoek van de donor kan volledig en uitgebreid plaats vinden, zodat men over de toestand van het donororgaan goed is georiënteerd.

In het geval dat de donor niet meer leeft of er geen tijd is voor programmering i $\mathrm{v}$ de acute noodzaak de ontvanger van het orgaan te voorzien, zal men zo snel mogelijk moeten handelen en niet in staat zijn de orgaanfunctie, anders dan door een paar vragen, die op het functioneren van het orgaan in het verleden wijzen, vast te stellen.

In het algemeen zal men kunnen stellen, dat de orgaanfunctie bij jonge volwassenen normaal zal zijn en het orgaan dus geschikt zal zijn om te worden getransplanteerd. Juist in de groep van 18 tot 30 jaar nu komen de meeste verkeersongevallen voor, zodat deze volwassenen ook de grootste groep gevers is geworden.

\section{HET DILEMMA VAN HET LEVENDE DONORORGAAN EN DE DODE DONOR}

Uit het bovenstaande is wel duidelijk geworden dat een orgaan dat wordt overgeplaatst, in uitstekende conditie dient te zijn, wil het zijn functie in die ontvanger goed kunnen uitoefenen. Dat betekent dus dat het orgaan levend moet zijn en dat het alleen zin heeft het orgaan over te plaatsen indien men weet dat het nog goed functioneert. Een dilemma doet zich voor als men het orgaan van een dood mens wil gebruiken.

Ten aanzien van de hoornvliezen van het oog, die overgeplant kunnen worden op ogen waarvan het hoornvlies is beschadigd, zodat daardoor aan blinden het gezicht kan worden terug gegeven, zal dit niet tot grote moeilijkheden aanleiding geven. Het hoornvlies is $\mathrm{nl}$ niet met bloedvaten voorzien en ontvang zijn voeding vanuit de omgeving door diffusie. Het blijft na de dood van de mens daardoor nog enige tijd goed en als men maar binnen een bepaalde tijdslimiet dit hoornvlies afneemt zal het geschikt zijn voor overplanting. Niet altijd geldt dit, daar een langdurige doodstrijd of het gebruiken van bepaalde medicamenten e d hoornvliezen ongeschikt maken voor tansplantatie. Verder gelden niet zulke strikte eisen van compatibiliteit der weefsels juist doordat een hoornvlies niet van een bloedcirculatiestelsel is voorzien. 
Ook met bloed is het mogelijk om dit na de dood van de mens te gebruiken voor transfusie. In Rusland wordt dit nogal eens gedaan. Het bloed wordt uren na de dood afgenomen (na aanvankele stolling is het dan weer ontstold). Bij zo 'n afneming kan veel meer bloed worden genomen dan van een levend mens kan worden verkregen.

Anders wordt het met de overige organen. De dood treedt niet op hetzelfde moment voor het gehele lichaam in. Het is een proces in tijd. De weefsels zijn afhankelijk van de zuurstofvoorziening door het bloed. Als het hart niet meer klopt of als het bloed geen zuurstof meer krijgt (b v door stilstand der ademhaling), dan wordt aan de weefsels van het lichaam geen zuurstof meer aangeboden. Het ene weefsel is daar veel gevoeliger voor dan het andere. Hersenweefsel kan dit bij de mens op middelbare leeftijd slechts 5 á 10 minuten volhouden. Op oudere leeftijd soms minder dan 1 minuut. Nieren leven nog wel een half uur nadat zij geen zuurstof meer krijgen aangeboden. Nagels en haren kunnen nog 2 dagen na de dood groeien.

Indien men dus van een dood mens een orgaan wil overplanten, dan moet dat zeer snel na het intreden van de dood gebeuren. Men kan deze tijdsperiode wat groter maken door te zorgen dat na de dood de bloedcirculatie kunstmatig op gang wordt gehouden en het bloed ook van zuurstof wordt voorzien. Dat betekent hartmassage en beademing. Op die manier kan men de nieren na de dood van de mens nog enige tijd in goede conditie houden, zodat het operatieteam gereed kan worden gemaakt om de nieren te verwijderen en vervolgens over te planten. Hier komt de kernvraag naar voren en wel: wanneer is iemand dood? Want het lijkt medisch-ethisch duidelijk dat het afnemen van een orgaan $n a$ de dood ten behoeve van een ander levend mens geen bezwaren ondervindt. Het afneem van een orgaan voor de dood, waardoor de donor ten gevolge van deze ingreep zal sterven, zal medisch-ethisch niet geoorloofd zijn. Het belang van de weliswaar doodzieke gever wordt niet gediend, en wordt opgeofferd aan het belang van een ander, eveneens ziek medemens.

Aan de ene kant zal de arts dus geen orgaan willen afnemen zolang de donor nog leeft, aan de andere kant zal hij zo snel mogelijk een orgaan willen verwijderen om het levend en in goede conditie over te kunnen planten. Het exacte tijdstip van de dood is daardoor niet alleen juridisch maar ook medisch van belang geworden. De criteria van de dood - de regels volgens welke men de dood van een mens kan vaststellen - hebben een uitermate grote betekenis gekregen. 


\section{CRITERIA VAN DE DOOD}

Om dit voor de orgaantransplantatie hoogst actuele probleem op te lossen, zijn de criteria van de dood aan uitgebreide beschouwingen, gesteund door onderzoekingen, onderworpen. Ook hebben verschillende instanties de behoefte gevoeld een uitspraak over die criteria te doen. Dit is door de paus geschied. Dit is indertijd door generaal De Gaulle geschied en diverse landelijke en wereldlijke verenigingen van wetenschapsmensen hebben bepaaalde criteria aanvaard. Leven $\mathrm{nu}$ is aan een geordend geheel van activiteiten en structuren, dus van functies en vormen, gebonden. Zodra deze geordende totaliteit uiteenvalt is de grens van het leven naar de dood overschreden.

Men kent nu zekere tekenen van de dood, zoals het optreden van lijkstijfheid en lijkevlekken. Het duurt enige uren eer deze verschijnselen tot stand komen. $\mathrm{Zij}$ kunnen dus geen dienst doen als criteria indien orgaantransplantatie is voorgenomen.

Algehele hersendood heeft tot gevolg dat de geordende totaliteit waarvan hierboven sprake was als voorwaarde voor leven, uit elkaar valt. De volledige hersenfunctie moet totaal en irreversibel uitgevallen zijn. Vroegtijdige vaststelling van algehele hersendood is dan ook van essentieel belang voor het snel beslissen over het opgetreden zijn van de dood.

Algemeen worden de volgende criteria aanvaard of aangenomen:

1, Er mag geen spontane bloedcirculatie meer zijn, althans nie door de hersenen.

2. Er mag geen spontane ademhaling meer zijn.

3. De patiënt mag niet meer reageren op de allerhevigste pijnprikkels.

4. Het electro-encephalogram dient iso-electrisch te zijn gedurende 24 uur.

5. De basale laboratoriumwaarden in het bloed dienen normaal te zijn.

6. Deze criteria gelden niet als er sprake is van vergiftiging of onderkoeling.

In het kort komt het hier op neer dat deze regels allen slaan op een algehele hersendood. De eerste drie genoemde criteria zijn de $\mathrm{z}$ g klinische criteria, waaraan nog kan worden toegevoegd, dat ook de $\mathbf{z} \mathbf{g}$ hersenstamreflecten moeten zijn uitgevallen. Het vierde is een technisch criterium en vijf en zes zijn voorwaarden om de bovenstaande criteria te doen gelden. Een van die belangrijkste criteria is dat van het electro-encephalogram. Dit is een afleiding van de hersenen waar- 
bij verschillen in electrische voltages worden vastgesteld zoals die bij levende hersenen optreden.

Zodra de hersenen zijn afgestorven verdwijnen deze verschillen in voltages en krijgt men een zogenaamde isoelectrische, $d \mathrm{w} z$ een geheel vlakke lijn op de afleesapparatuur van het electro-encephalogram. Dat betekent dat er geen hersenactiviteit meer is. Men is van mening dat dit na 24 uur nog zo moet zijn, voordat men kan aannemen dat er werkelijk hersendood is, tenzij men gedurende 4 of 6 uur - de tijdstippen verschillen nog - continu een vlakke lijn registreert ook bij maximale stimulering van de hersenactiviteit. In gevallen van vergiftiging en onderkoeling gaat dit criterium niet op. Vandaar ook de uitzondering hiervoor. In zuilke gevallen kan men dagenlang een vlak of wel iso-electrisch E E G vinden zonder dat er sprake is van hersendood. Herstel kan dus nog optreden.

Hiermede is ook in de regel het zwakke punt van bovenstaande redenering blootgelegd. Het is weliswaar zo dat algehele hersendood leidt tot een iso-electrisch E E G, maar het omgekeerde kan niet gesteld worden en wel dat een isoelectrisch E E G betekent dat algehele hersendood is opgetreden. Dit betekent dat het criterium van het E E G slechts een relatief criterium is en geen absoluut bewijs voor hersendood of men nu 4 of 6 uur, dan wel 24 uur registreert.

Er zijn in wezen drie opvattingen over de coodscriteria, $d \mathrm{w} \mathrm{z}$ hoe men de algehele hersendood vaststelt. De eerste is de Amerikaanse en ook Engelse opvatting. De diagnose dood wordt gesteld op de klinische symptomen. Een E E G wordt niet noodzakelijk geacht. Een irreversibel coma, dus een niet weer teruggaande toestand van bewusteloosheid met het ontbreken van spontane ademhaling gedurende 24 uur (soms wel teruggebracht tot 1 uur! ) wordt voldoende geacht om de patiënt dood te verklaren. Het tweede is de Franse opvatting waarbij de klinische symptomatologie als in de vorige opvatting eveneens wordt vereist maar bovendien een langdurige isoelectrische $\mathrm{E} \mathrm{E} \mathrm{G}$ registratie met daling van de spontane bloeddruk en temperatuur gedurende een bepaalde tijd. In de derde plaats bestaat de Oostenrijkse (Duitse) opvatting, die het ondubbelzinnige bewijs van hersendood vereist hetgeen momenteel alleen mogelijk is door een dubbelzijdige serie van röntgenfoto's van de bloedvaten van het hoofd nadat een röntgencontrastmiddel is ingebracht. Indien er algehele hersendood is zal er geen bloedstroom meer aanwezig zijn en het contrastmiddel niet in de hersenvaten terecht komen. Men kan ditzelfde ook bereiken door radio-actieve stof in de bloedvaten naar de hersenen te spuiten en dan te meten of er radio-activiteit 
in die hersenen komt. Dit is een niet-ingewikkelde ingreep. Wel is bepaalde apparatuur vereist. Alleen in de Duits-Oostenrijkse opvatting wordt als de klinische symptomatologie en het $\mathrm{E} \mathrm{E} \mathrm{G} \mathrm{passen}$ bij algehele hersendood het ondubbelzinnige bewijs hiervoor gelevered. In feite is dan ook alleen deze opvatting het juiste criterium voor de dood. $\mathrm{Nu}$ is het onmogelijk om in alle gevallen van dood op deze wijze de hersendood te bewijzen. Dat is ook niet nodig. Indien men aannemelijk kan maken dat de bloedcirculatie en/of de ademhaling gedurende 15 minuten zijn uitgevallen dan is algehele hersendood ingetreden. Hierbij dient wel opgemerkt te worden dat de discrepantie tussen schijndood en dood niet zo eenvoudig is. Bij schijndood bestaat wel degelijk circulatie en respiratie, zij het dat deze nauwelijks waarneembaar is. Die 15 minuten observatie geven moeilijkheden indien ademhaling en bloeddruk kunstmatig op peil worden gehouden. Dan komt de vraag in hoeverre er algehele hersendood is en gaat het criterium van de opgehouden doorbloeding een wezenlijke rol spelen. Maar ook hier loopt men het gevaar de redenering om te keren. Men zegt dan: als ik de kunstmatige ademhaling en bloedcirculatie stop zet zal deze patiënt binnen 15 minuten dood zijn. In wezen is hij dus al dood want dit kunstmatig op gang houden is onnatuurlijk. Deze redenering is ethisch en juridisch onaavaardbaar.

Het röntgenonderzoek van de hersenbloedvaten is meer belastend voor de patiënt dan alle andere genoemde onderzoeken. Het is daarom ook dat de mening wordt gehuldigd dat als het E E G duidelijk wijst op de mogelijkheid van algehele hersendood, eerst dan het bewijs dient te worden geleverd met het röntgenonderzoek.

Dit alles lijkt redelijk eenvoudig, maar is in de praktijk welhaast onhanteerbaar. Gezien de eis van 4 tot 6 uur continu registratie van het electro-encephalogram of wel 24 uur met 2 registraties en eerst daarna verrichten van het onderzoek naar de bloeddoor stroming van de hersenen, zal het toch altijd enkele uren na de dood zijn eer het vaststaat dat de patiënt is overleden. Dit is voor transplantatie van vitale organen als nieren, longen, hart etc. onaanvaardbaar. Zij kunnen dan niet meer worden getransplanteerd.

Bij ernstige hersenletsels (verkeersongeval!) zal men om diagnostische redenen een röntgenonderzoek van de hersenvaten doen om de mogelijkheden van therapie te beoordelen. Dan kan het geschieden, dat de arts reeds vroeg constateert dat er geen cerebrale bloeddoorstroming meer is en hersendood dus zeer aannemelijk is. 
Het kunstmatig de circulatie en ademhaling in stand houden in afwachting van de beslissing op het $\mathrm{E} \mathrm{E} \mathrm{G} \mathrm{en} \mathrm{het} \mathrm{röntgenonderzoek,}$ kan er toe bijdragen dat de nieren geschikt blijven voor transplantasie. Veel moeilijker wordt het voor hart en longtransplantatie. Het overbrengen van een levend hart, wat voorwaarde is, betekent dat het hart nog spontaan moet kloppen. Welnu de eis dat de circulatie moet stilstaan, is in tegenstrijd met het ontnemen van een kloppend hart. Slechts met de allergrootste voorzorgen is het mogelijk om een nog levend kloppend hart over te brengen, terwijl de donor op grond van de criteria klinisch dood is. Dit is mogelijk bij b v totale verwoesting van de hersenen door een verkeersaccident waarbij de hersenstam nog intact is en het hart nog even klopt. (Het is verder zelfs aannemelijk, dat het hart buiten de invloed van de hersenstam, dus ook bij totale hersendood nog enige tijd autonoom kan kloppen en een beperkte bloedcirculatei op gang kan houden). De arts, die dan heel spoedig werkelijke dood van de patiënt kan verwachten, kan dan zodra het hart of de ademhaling stopt (als het stopt zal de ademhaling ook stoppen en omgekeerd als de ademhaling stopt zal ook het hart stoppen) door nauwkeurige observatie van de patiënt, op het goede ogenblik het chirurgische team de gelegenheid geven het hart zo snel te verwijderen na de dood van de gever, dat het nog levend kan worden overgeplant.

\section{HANTERING IN DE PRAKTIJK}

Een van de eerste eisen voor een goede hantering van deze problematiek in de praktijk is dat het team van behandelende artsen niet het team is van de transplanterende artsen.

In de eerste plaats zou het voor de transplanterende artsen een te grote - onbewuste - verleiding kunnen zijn, om iemand die nog leeft maar sterven sal, als dood te beschouwen en hem de organen af te nemen.

Uit hun opdracht is dit begrijpelijk. Zij willen de levende die baat moet hebben van het te ontvangen orgaan, zo goed, zo best en zo snel mogelijk helpen. Om dit conflict voor hen te vermijden, zullen zij pas op mogen treden nadat het behandelend team zich heeft teruggetrokken, omdat de dood van de patiënt was vastgesteld. Het is in de tweede plaats bovendien duidelijk dat het een psychische, zware belasting, zowel op de artsen als op familie, zou leggen, indien eerst de artsen strijden voor het leven van de patiënt en vervolgens verzoeken om zo snel mogelijk een nog levend orgaan uit de patiënt te mogen halen. Praktisch is dit een te grote spanning. Wel moet bij 
het behandelende team de bereidheid bestaan om het transplanterende team te helpen; anderzijds moet het transplanterende team de beslissing van het behandelende team over het al of niet dood zijn van de donor respecteren.

In Nederland is een dergelijke scheiding algemeen aanvaard. Zodra dan ook de behandelende artsen van mening zijn dat de patiënt is gestorven, zodat de doodsverklaring kan worden afgegeven, wordt het transplantatie-team gewaarschuwd en overleg gepleegd met de familie. Als een codicil aanwezig is waarin patiënt schriftelijk heeft beschikt dat zijn organen na zijn dood voor transplantatie ter beschikking kunnen worden gesteld, is dit voldoende. Ook een schriftelijke verklaring van de naaste familie, na de dood van de patiënt, afgegeven, wordt aanvaard. Terstond kan tot verwijdering van de betreffende organen worden overgegaan.

Het ligt nog iets anders bij mensen die door een verkeersongeval of een ander ongeluk zijn omgekomen. Daarbij geldt in Nederland dat alleen een gemeentelijke lijkschouwer de dood mag verklaren. Indien echter de organen voor transplantatie geschikt zijn en er toestemming daarvoor aanwezig is, duurt de procedure te lang indien aan alle wettelijke eisen wordt voldoen. De gemeentelijke lijkschouwer moet de dood constateren en dit aan de officier van justitie opgeven in verband met mogelijke strafbare gebeurtenisssen. De officier van justitie bepaalt op een gegeven moment of het lijk kan worden vrij gegeven dan wel in beslag wordt genomen. Tot aan de beslissing van de officier mag in Nederland met het lijk niets gedaan worden. Het is duidelijk dat er dan geen organen voor transplantatie kunnen worden gebruikt, want zij zijn bij het vaststellen van een dergelijke beslissing niet geschikt meer. De afspraak is nu dat dit wel mag geschieden, de organen dus kunnen worden verwijderd, wanneer er toestemming van de overledene of van de familie aanwezig is. De gemeentlijke lijkschouwer vermeldt in zijn rapport aan de officier van justitie dat $b$ v de beide nieren ontbreken. De officier van justitie gaat hier verder niet op in en geeft het lijk vrij, als de andere omstandigheden hem hiervoor aanleiding geven.

Voor het overige is er in Nederland geen wettelijke regeling. Men gaat uit van de eis, dat of de overledene of de familie toestemming dient te hebben gegeven.

De situatie in Zuid-Afrika, althans in Kaapstad, is niet veel anders dan in Nederland. De neuro-chirurg Prof Dr J C de Villiers in Kaapstad, die veelal verantwoordelijk is voor de doodsverklaring van 
patiënten waarvan de organen worden gebruikt voor transplantatie, ook bij de harttransplantatie, vertelde dat hij met zijn staf al of niet beslist over het dood zijn van de patiënt. Zelf heeft hij niets met transplantatie te maken en wil daar ook geen enkele verantwoordelijkheid voor nemen. Uiteraard waarschuwt hij wel het transplantatieteam, indien het duidelijk is, dat op korte termijn een potentiële donor zal sterven. Hij hanteert de criteria voor de dood zeer scherp. Het voornaamste acht hij nog steeds de klinische gegevens en het klinisch onderzoek. Wel kunnen apparaten van nut zijn. Voor de primaire diagnose van het hersenletsel maakt hij veelvuldig gebruik van het röntgenonderzoek der hersenvaten, in een zeer vroeg stadium dus. Verder maakt hij weer regelmatig een electroencephalogram, dat op hersendood wijst, als het gedurende 4 uur iso-electrisch is. Maar dit moet dan wel overeenkomen met de klinische situatie en bovendien moet er uitdrukkelijk intoxicatie en onderkoeling zijn uitgesloten. Algehele hersendood is voor hem het belangrijkste criterium. Laesies van de frontale kwab waardoor wel een persisterend coma ontstaat, maar de circulatie en respiratie intact kunnen blijven functioneren, worden door hem uiteraard niet als hersendood beschouwd. Men noemt die situatie een partiële hersendood en trekt daaruit dan ook niet de conclusie dat de dood van de patiënt is ingetreden.

Het is bij de patiënten, die als donor fungeerden steeds zo geweest, ook met de harttransplantaties, dat inderdaad de dood aanwezig was, met andere woorden, dat de hartwerking, de circulatie niet meer spontaan op gang was. Wel is het zo dat het transplantatie-team in heel korte tijd na het stoppen van het hart, zijn werk heeft kunnen verrichten. Bij mensen die door een ongeval zijn omgekomen, moet de doodsverklaring door twee artsen worden afgegeven, waarvan één minstens een senioriteit dien te hebben van 5 jaar. Als men bovendien nog een orgaan wil tranplanteren, behoeft men de toestemming van de districtsgeneesheer van de plaats waar de patiënt woonde. Dit geeft in de praktijk nog wel een oponthoud, maar het is zo bij de wet geregeld.

Al met al moet worden gesteld dat de behandeling van de gewone patiënten die sterven en wiens organen misschien voor transplantatie in aanmerking komen, in Nederland, en Kaapstad dezelfde zijn, dat de criteria op beide plaatsen even grondig en scherp worden gehanteerd, maar dat bij de traumatische gevallen, de verkeersongevallen dus, de criteria in Kaapstad zwaarder zijn dan in Nederland. Daardoor zal het tijdsverloop tussen de dood van de gever en het ontnemen van de organen in Kaapstad langer kunnen zijn dan in 
Nederland. Dit heeft een nadelige invloed op het aantal organen, dat voor transplantatie beschikbaar komt.

\section{SLOTBESCHOUWING}

Medisch-ethische overwegingen bij de orgaanstransplantatie brengen met zich mee, dat geëist moet worden dat aan een aantal essentiële zaken wordt voldaan. Principiële afwijzing is uit medisch ethische overweging niet naar voren te brengen. Wel kan afwijzing plaatsvinden op grond van reglieuse opvattingen.

Die eisen waaraan dient te worden voldaan bestaan uit:

1. Toestemming van de patiënt, het liefst bij codicil, eventueel via de naaste familie.

2. De donor-organen voor transplantatie dienen in een goede conditie te zijn en te leven.

3. De ontvanger moet in een zo goed mogelijke toestand zijn voor de transplantatie.

4. Tenslotte dient ook gever in een goede conditie te zijn. Als deze echter stervende is en zijn organen gebruikt zouden kunnen worden, dienen de criteria van de dood met grote nauw keurigheid te worden gehanteerd. Slechts van een dood mens mogen

pde organen worden afgenomen om anderen te helpen. Dit brengt mee dat het behandelend team van medici uit andere artsen dient te bestaan dan het transplantatie-team.

Het hart vervult in de menselijke geest een bijzondere plaats. Het wordt vaak beschouwd als het middelpunt van de mens, van waaruit zijn leven wordt gereguleerd, zowel zijn lichaam als zijn ziel. Deze betekenis van het hart komt voort uit de tijden dat men nog weinig wist van de samenstelling van het menselijk lichaam. Reeds lang is echter bekend, dat het hart als taak heeft het rondstuwen van het bloed door zijn vaten. Het is niets anders dan een ingenieuze spierpomp. Met het hart wordt alleen deze pomp overgeplaatst, niet de ziel of de geest van de gever.

Deze beschouwing over het hart doet echter wel denken aan de hersenen. Immers voor sommigen geldt dit orgaan als de zetel van 's mensen ziel. Hoe men nu de hersenen ook beschouwt, al of niet zetel van de ziel of de geest van de mens, in ieder geval vervullen zij een functie in de verbinding tussen lichaam en ziel.

De persoonlijkheidstructuur, het karakter van de mens ligt (zeker ten dele) verankerd in zijn hersencellen. Daar zijn ook de gebieden die de mens het vermogen tot associaties en tot abstract denken geven. 
Kunnen hersenen overgeplant worden? En als dat mogelijk is, is het dan medisch-ethisch geoorloofd? Het antwoord op de eerste vraag lijkt ontkennend te moeten luiden. Men kan zich niet voorstellen, dat een zo ingewikkeld samenstel van zenuwen, vaten en zenuwweefsel zal kunnen worden overgeplant met het aanleggen van voldoende verbindingen om het orgaan te doen functioneren. Toch bedenke men, dat deze opvatting in het verleden vaak is gehuldigd voor zaken, die wij thans normaal vinden. Het is dus verstandig om te veronderstellen, dat het op een gegeven ogenblik wel kan. Als dan reeds nu aandacht besteed wordt aan de medisch-ethische, godsdienstige, juridische en andere problemen, die dan zullen ontstaan, zou bij uitzondering in de medische wetenscha ${ }^{\prime}$ de medisch-ethische bezinning vooraf gaan aan het experiment.

De vragen die zich voordoen rijzen als grote bergen op. De gever mag niet voldoen aan de criteria van de dood. Er mag geen hersendood zijn. Is dat geoorloofd? En zullen criteria om het tijdstip van afneming, dus van het doen sterven van de gever, moeten worden aangelegd?

De ontvanger zal zijn eigen hersenen moeten missen. Hij wordt dus gedood om in leven te blijven. Het totaal van de ingreep levert dus een dode op, die moedwillig ter dood wordt gebracht en een levende, die gedood wordt om te blijven leven.

Mag dit allemaal wel? Er wordt toch grote en onherstelbare schade aan de gever aangericht?

Het probleem is hiermede nog lang niet grondig genoeg gesteld. De verbinding met de ziel van de ene mens, in feite onlosmakelijk aan zijn lichaam gebonden, wordt overgebracht naar de ander. Gaat de ziel met de hersenen mee? En is het dan wel geoorloofd om de mens van zijn ziel te beroven en er een ander voor in de plaats te stellen? Past de nieuwe ziel bij het andere lichaam? En wie is dan de mens, die ontvanger van de hersenen van een ander is: zichzelf met andere hersenen voortbestaand of de gever, die nu een ander lichaam heeft?

Het wordt een beangstigende beschouwing. De antwoorden dienen nog gevonden te worden.

Tenslotte rijst de vraag of zo 'n grote hoeveelheid aan mankracht, energie en geld die besteed wordt om transplantatie te doen plaatsvinden, opweegt tegen het nut, en of het uit medisch-ethisch oogpunt verantwoord is om al dit werk te verrichten. 
Ten aanzien van de niertransplantatie kan hier zeker bevestigend op worden geantwoord. Het is mogelijk door een niertransplantatie iemands leven jarenlang te verlengen en in kosten omgeslagen valt dit erg mee. Dit is geen reden om hier een medisch-ethisch bezwaar te zien. Bovendien is daar het voordeel dat de levende mens één nier kan afstaan, terwijl hij zelf blijft leven en de dode mens twee nieren kan leveren, zodat in zekere zin een dubbele hoeveelheid nieren ter beschikking zouden kunnen staan. Eén dode gever kan twee levenden aan een nier helpen.

Heel anders ligt het ten aanzien van de harttransplantatie. Het vele werk wat daaraan wordt verricht is boeiend, spannend en in zekere zin ook nuttig door de ervaring die men krijgt. Toekomst zit er echter naar mijn mening niet in. De hoeveelheid van donor-harten die nodig is, zal altijd ver blijven onder het aantal dat vereist is. Dat komt omdat ieder mens slechts één hart heeft en vele harten verloren gaan omdat zij niet geschikt zijn voor transplantatie. Men zal dus een andere oplossing moeten vinden, waarbij gedacht kan worden aan transplantatie van dierlijke harten of de fabricatie van volledig kunstmatige harten. In beide gevallen zullen de medisch-ethische eisen, die bij harttransplantatie wat meer moeilijkheden geven dan bij niertransplantatie, vervallen.

Het nut van harttransplantatie moet dan ook gezien worden in de ervaring die men opdoet bij het verrichten van zulke grote, ingrijpende operaties. En zeer zeker ook in het onderzoek en beheersen van de afstotingsreacties van dergelijke grote organen.

Kaapstad neemt daarin een vooraanstaande plaats in deze wereld in.

C VAN DER MEER Vrije Universiteit Amsterdam Maart 1975 